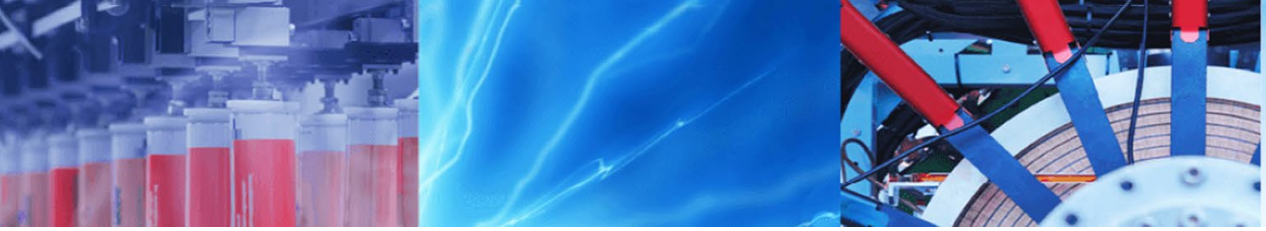

Research Article

\title{
Evaluation of the effect of body fluid analogs on the parameters of nanofiltration during the purification of swimming pool water
}

\author{
${\text { Edyta } \text { Łaskawiec }^{1} \text { (D) Mariusz Dudziak }}^{1}$ (D) Joanna Wyczarska-Kokot ${ }^{1}$ (D)
}

(c) The Author(s) 2019 OPEN

\begin{abstract}
This study presents the possible application of membrane nanofiltration for purifying swimming pool water by removing compounds from human body secretions. The effect of the matrix (swimming pool, demineralized, tap water) on the analyzed pollutants was evaluated. We used asymmetric flat membranes (polyamide-thin film composite) in a dead-end filtration system. The effect of the matrix on the transport properties of the membranes was noticeable. A maximum reduction in value of permeate flux was obtained for $15.6 \mu \mathrm{L}$ fluid analog solution/L of pool water. For all the analyzed matrices, a distinct reduction in the value of relative permeate flux was obtained along with an increase in the content of the investigated compounds in the feed. There was a marked increase in the separation properties along with an increase in the pollutants. The average value of the retention coefficient for total organic carbon was $87.21 \%$ and $79.67 \%$ for the concentrations of 3.90 and $15.60 \mu \mathrm{L}$ fluid analog solution/L of pool water, respectively. This study provides evidence that further research into highly effective solutions for purifying pool water would be beneficial.
\end{abstract}

Keywords Water treatment - Closed circuit · Total organic carbon · Pressure-driven membrane processes · Secretions of the human body

\section{Introduction}

Every public swimming pool facility must have its own water treatment circuit to maintain the required physicochemical and microbiological standards of water [1-4]. Such circuits are an example of closed-loop circuits where water is treated and disinfected continuously during the operation of the facility. Disinfection of water is very important in the prevention of growth of pathogens. The most common source of water supply to the swimming pools is water mains, and rarely, it is deep well intakes. The supplied water contains organic and inorganic compounds, which are naturally present, in addition to the disinfection by-products (DBPs) that are generated during the course of its treatment [5]. Additional pollutants may enter the water mains during the course of its distribution to various pool facilities [6]. However, the primary factors that significantly reduce the quality of water in basins are organic micropollutants-introduced by the users of the pool (e.g., residues of cosmetic products) —and products of human metabolism (e.g., saliva, urine, sweat, and epidermis) $[7,8]$. More than 600 different compounds have been identified which belong to the class of DBPs, which cause harmful effects on the human body $[9,10]$.

Filtration on filtration beds is a common technique of water treatment across various swimming pool facilities. It is usually accompanied by the process of contact coagulation. However, the effectiveness of coagulation in the removal of micropollutants (especially the small-particle micropollutants) is low, on a level of $10-20 \%[11,12]$. In addition, water treatment systems in many pool facilities still use single-layer sand filtration beds that do not ensure complete elimination of pathogens [13]. Improvement of the effectiveness of the filtration beds may be achieved

Edyta Łaskawiec, edyta.laskawiec@polsl.pl | Institute of Water and Wastewater Engineering, Silesian University of Technology, Konarskiego 18, 44-100 Gliwice, Poland.

SN Applied Sciences (2019) 1:566 | https://doi.org/10.1007/s42452-019-0568-3

Received: 30 January 2019 / Accepted: 6 May 2019 / Published online: 15 May 2019 
by using an additional sorption layer of activated carbon. Depending on the type of micropollutant, the removal efficiency can be at a level of $20-85 \%[13,14]$.

The water quality in a swimming pool is specifically affected by various factors, including the quality of the water supplied to the circuit, the load of the facility (the number of swimmers), the treatment technology (including the type of the filtration bed), and the type of facility (indoor or outdoor pool). To maintain the required microbiological and physicochemical standards, it is necessary not only to use an appropriate water treatment technology but also to disinfect it. Chemical disinfecting agents reduce the growth of pathogens, such as Escherichia coli and Legionella sp., in swimming pool water (POOLW) [15, $16]$, and they also react with various pollutants present in the water. The presence of DBPs in POOLW has become a more common problem that has been broadly studied $[7,17,18]$. Due to the progress in instrumentation technology in the last few decades, several DBPs in POOLW have been identified $[19,20]$. The common presence of trihalogenomethanes (THMs), halogen-acetic acids (HAAs), halogen-acetonitrile (HAN), chloramines (CAM), and many other chemical compounds demonstrates that a long and/ or systematic contact with water and air in POOLW may result in serious consequences to the health of the users of such facilities [10, 20, 21].

Mains water in swimming pool circuits contains not only natural organic matter (NOM) but also chlorides, bromates, and DBPs, including chloramines and bromides $[5,7]$. It is also used to make up for losses due to splashing and absorption of water by the swimwear. A common practice among pool staff is to dilute water in the circuit if the concentration of combined chlorine or chloroform exceeds the standard value.

However, natural products of human metabolism are known to be the largest contributors of DBPs. It is estimated that a single swimmer during an hour of physical activity excretes $50 \mathrm{~mL}$ of urine and $200 \mathrm{~mL}$ of sweat resulting in an increase in the content of nitrogen-based organic compounds. These compounds react easily with chlorinebased disinfectants [22-25]. The concentration and composition of DBP precursors classified as body fluid analogs (BFAs) are strongly correlated with the number of persons using the pool (this value is usually given as the number of persons per hour or per surface (in meter square), their hygiene habits, and the intended use of the pool (swimming, children's recreational, jacuzzi, etc.)). However, previous studies have confirmed the presence of urea, ammonia, uric acid, creatinine, creatine, lactic acid, citric acid, hippuric acid, uracil, ornithine, chlorides, sulfates, cations $\left(\mathrm{K}^{+}, \mathrm{Na}^{+}, \mathrm{Ca}^{2+}, \mathrm{Mg}^{2+}\right.$, and $\left.\mathrm{Zn}^{2+}\right)$, and amino acids (histidine, glycine, cysteine, asparagine, lysine, arginine, and guanine) in POOLW $[7,23]$. It has been confirmed that the reactivity of human body fluids with chlorine is greater than that of NOM with chlorine. A mixture of BFA forms more chloroacetic acid (e.g., HAA) than trichloromethanes (e.g., THM). Citric acid increases the formation of THM and HAA $[7,17]$. Another DBP precursor is creatinine, which forms stable chloramines identified as dichloramines [24]. The presence of amino acids contributes to the formation of not only chloramines but also cyanogen chlorides. Trichloramines are also formed in the presence of creatinine, urea, histidine, and arginine [7]. Urine also contains active components and metabolic products of various medications such as painkillers and antibiotics, which along with the residues of cosmetics might enter the water [20,23].

Even though many DBPs are present at concentrations below $1 \mathrm{mg} / \mathrm{L}$ in POOLW [8], their presence is still harmful to humans. It has been confirmed that micropollutants in the form of DBPs produce various enzymes that cause oxidative stress in the cells of living organisms [9]. Previous studies have confirmed the genotoxic, cytotoxic, and mutagenic properties of DBPs present in POOLW [8-10, 26]. High rates of genotoxicity have been associated with DBPs with low molar mass [10]. A majority of DBPs has a molar mass below $1000 \mathrm{~g} / \mathrm{mol}$ and as much as $30 \%$ of them are those with a molar mass below $200 \mathrm{~g} / \mathrm{mol}[25$, 26]. DBPs cause irritation of the mucous membrane when the person is in the POOLW and prolonged contact with DBPs may cause various health issues such as asthma, bladder cancer, and atopic dermatitis [20, 26, 27]. Thus, the benefits of swimming can be achieved only when the negative effect of toxic substances has been reduced. Therefore, it is necessary to look for effective ways to treat POOLW, which will make it possible to eliminate both precursors and the products of their reactions with DBPs.

Continuous monitoring of water quality is immensely important to the operators of the pool facility because they are aware of their responsibility for human health and of the legal consequences that they will face if they fail to perform their duties. In addition to an extended physicochemical (total concentration of trihalomethanes, chloroform, nitrates, and oxidizability) and microbiological analysis, continuous measurements, which are usually performed on a daily basis, include measurements of $\mathrm{pH}$, redox potential, free chlorine, bound chlorine, and turbidity. This analysis is necessary to evaluate the quality of POOLW; however, they do not present a complete picture of the presence of DBPs. Among the parameters that describe anthropogenic pollution, usually the most important are believed to be the concentration of total organic carbon (TOC), total nitrogen (TN), ultraviolet absorbance at a wavelength of $254 \mathrm{~nm}\left(\mathrm{UV}_{254}\right)$, and turbidity [10]. A particularly important parameter that indicates the presence of body fluids in POOLW is the concentration of dissolved organic carbon (DOC) [5]. The concentration of DOC 
is related to the number of people bathing and the formation of DBP; consequently, monitoring and reducing the concentration of DOC are very important to maintain the quality of POOLW [5].

Along with the quality of POOLW, it is important to analyze the correlation between the selected parameters of quality. For example, the presence of trihalomethanes and heterocyclic aromatic amines is strongly correlated with the content of TOC in POOLW but is only weakly correlated to free chlorine [28-30]. Moreover, in the case of analysis of chemicals related to body fluids, measurement of TOC is particularly important because it indicates the potential for the formation of trihalomethanes. Although, as a standard, $\mathrm{UV}_{254}$ is a frequently analyzed parameter and the quality of disinfected water is assessed based on this value, till date, no correlation has been identified between the concentration of DBPs and the values of $\mathrm{UV}_{254}$.

$\mathrm{UV}_{254}$ is a measure of aromaticity and may be an indicator between the potential of formation of THM and HAA; however, it is not a direct determinant of the concentration of DBPs $[28,29]$. In addition to the commonly used indicators of water quality, it is also recommended to measure the content of total inorganic salts (TDS), inorganic nitrogen (ammonium), and organic nitrogen [30].

Despite very detailed descriptions of the problem of pollution with human body fluids in swimming pool water given in multiple publications worldwide, the water treatment technologies continue to concentrate on bed filtration (filtration with contact coagulation). Departure from use of single-layer sand beds to use of multilayer beds or zeolite fillings in swimming pool facilities has certainly significantly improved the quality of water in the circuits. However, upgrade processes are performed most of all in newly built facilities. On the other hand, the technological progress achieved in water filtration still does not solve the problem of fine-particle pollution in the circuits (water is changed once a year), which are not removed in the course of filtration processes [11-14]. Another issue that, in the opinion of the applicant, should be brought attention to, in the context of a change of swimming pool water treatment technology, is the high water consumption (and wastewater production) in swimming facilities. Because in the filtration process pollutants are gathered in filtration beds, which leads to gradual pressure loss, in order to meet the physicochemical and sanitary requirements concerning water quality, the filtration bed flushing process must be performed once every 2-3 days. In order to perform the filtration bed flushing process, $4-6 \mathrm{~m}^{3}$ of water (taken from an overflow tank) is required for every $\mathrm{m}^{2}$ of the filtration bed [4]. This process generates a large volume of wastewater, which is drained to the sewer system.

An alternative to classical treatment systems is pressure membrane systems that are highly effective in the removal of suspended solids, microorganisms, DBPs, and micropollutants $[12,31,32]$. Pressure membrane systems must be optimized for the operating parameters of the process if it has to be used for the treatment of POOLW, in addition to the observation and description of the phenomena that hinder their practical use in actual systems.

Thus, the reason for the experimental and computational works conducted is an evident lack of studies, that would describe the properties related to the transport and separation properties of substances associated with components of body fluids in unit nanofiltration (NF) processes and integrated systems, with the use of polymer membranes. Individual studies on the use of pressure membrane processes have focused on the total stream of pollutants [31-39] and have not analyzed a specific problem that may constitute an obstacle to the use of membrane systems in the future.

Pressure membrane systems have an advantage of the high degree of freedom when it comes to selecting the nature of the process and the operating parameters. Micro- and ultrafiltration processes focus on microparticles and macroparticles, which are usually inorganic particles, organic colloids, microbes, and dissolved organic substances [36-41]. Just the inclusion of pressure membrane processes in hybrid or integrated systems guarantees a high physicochemical and microbiological quality of the permeate, which enables its reuse [34, 35]. However, NF results in a high rate of removal of NOM and THM precursors [39]. The effectiveness of the removal of TOC and THM is strongly dependent on the membrane used [34].

Effective removal of TOC and DOC is by membranes with a low limit of cutoff, not exceeding $1000 \mathrm{Da}$ [21]. Moreover, NF membranes are more resistant to chlorine than that of reverse osmosis membranes and are useful in the removal of fine particles [39]. Removal of DBPs can be monitored by measuring the concentration of adsorbable organic halides (AOX), THM, and DOC [39, 40]. However, what makes their use difficult is a quick reduction in the transport properties of NF membranes due to the blockage of pores by organic compounds. Studies using model substances concern mostly wastewater that contributes to fouling (blocking of membrane pores as a result of reversible or irreversible sorption processes). The substances that have been frequently reported to cause fouling are humic acid, sodium alginate, and bovine serum albumin [42, 43]. It must be emphasized that the hydrophilic protein fraction also constitutes an important factor that blocks membranes [42]. An increase in the concentration of bivalent cations, a reduction in the $\mathrm{pH}$ of the solution, and an increase in the concentration of electrolytes significantly contribute to the contamination of membranes as a result of changes in the intermolecular electrostatic actions [44, 
45]. Given the presence of cations in BFA solutions, one can expect a reduction in the efficiency of membranes.

The efficiency (i.e., transport properties) of membranes is defined by the volume flux of permeate, which indicates the presence of feed material flowing through a unit of surface area of the membrane in a unit of time [46]. However, the separation properties are defined by the retention coefficient, i.e., the extent to which the substance present in the feed solution is stopped [47]. The inseparable element in the observation of membranes structures are nanoscopic analysis paths of their degradation and blocking effects. Ex situ methods such as scanning electron microscopy (SEM), atomic force microscopy (AFM), or spectroscopic ellipsometry allow for the in-depth supplementing knowledge on membrane-forming properties of the materials [48-52]. Information on the microstructure of the examined membranes, the possibility to create elemental maps, and pores' distribution topography are some of the selected applications of the modern imaging methods of fouling.

The consequences of fouling result in higher operating costs due to a reduction in the efficiency of membranes. Moreover, frequent cleaning of membranes reduces their separation properties and leads to the shorter service life of the epidermal layer, which is very important in the process of NF performed by using asymmetric membranes [42]. Identification of the polluting substances makes it possible to reduce or avoid the fouling of membranes. Therefore, the matrix in which those pollutants exist (e.g., deionized water, mains water, or POOLW) must also be analyzed to prevent fouling. Worldwide and in Poland, the effect of matrix on the transport and separation properties of pressure membranes has been studied [53-56]. However, to the best of our knowledge, no authors have analyzed specific compounds from the BFA class in different matrices with reference to the properties of membrane materials. Polymer membranes demonstrate, among others, sensitivity to chlorine $[50,51]$. As a result, it is important to conduct a comparative analysis of the effect of chlorine and other oxidants on the membrane-forming material and its susceptibility to biological decomposition and hydrolysis $[57,58]$. This will make it possible to determine the chemical cleaning (e.g., with sodium hypochlorite) of the studied material, e.g., with sodium hypochlorite [28]. Given the susceptibility of nitrogen compounds in the formation of DBPs, membranes can be cleaned with citric acid, which is a compound that does not contain such class of chemicals.

Therefore, in this study, we aimed to analyze the transport and separation properties of the commercial NF membrane. In addition, we tested the possibility of using this process to remove impurities from the group of substances analogous to the secretions of the human body.
The analysis was conducted, among others, based on the changes in the volume of demineralized water (DEMW) flux, permeate, and rinsing water. Furthermore, the values of removing impurities, based on selected physicochemical parameters studied the effect of the matrix (POOLW, DEMW, and tap water (TAPW)) on compounds from the BFA solution.

\section{Experimental procedures}

\subsection{Analyzes of physicochemical parameters}

Total carbon (TC), TOC, and DOC in POOLW samples, model solutions, feeds, and permeates (after $0.45 \mu \mathrm{m}$ filtration, PVDF syringe filter) were measured using a TOC- $L$ series analyzer by catalytic oxidation combustion at $680^{\circ} \mathrm{C}$ (Shimadzu). The $\mathrm{UV}_{254}$ values were measured using the UV VIS Cecil 1000 from Analytik Jena AG, with an optical path length of the cuvette d equal to $1 \mathrm{~cm}$. The $\mathrm{UV}_{254}$ value was determined based on the measurement method presented by the United States Environmental Protection Agency [59], and the final result of the analysis is presented as per meter. Turbidity was measured using EUTECH Instruments model Turbidimeter TN-100. Measurement of TN, total and free chlorine concentration in POOLW samples was made by the photometric method in cuvette tests using a VIS Spectroquant ${ }^{\circ}$ Pharo 300 UV spectrophotometer (Merck). The $\mathrm{pH}$ and redox potential in POOLW samples, model solutions, and feeds were measured with a multi-parameter inoLab $740 \mathrm{~m}$ (WTW, Measuring and Analytical Technical Equipment).

\subsection{Data regarding the pool facility}

Water samples were obtained from a swimming pool located in a primary school. The pool is constantly loaded during sports activities (from 10 to 25 people per hour). Modernization of the water treatment cycle, covering the basin, and fitting the elements in the facility took place in 2016. The water is continuously treated in a closed circuit, and its losses are supplemented up with TAPW. The facility operates during the school year. During the holidays, there is a technological break, during which the elements in the circulation are cleaned, and the water is wholly exchanged with fresh TAPW. Purified water flows through the overflow gutters and is transported to the overflow tank via pipelines. The water is treated by the process of contact coagulation (aluminum coagulant) and pressure filtration (multilayer filter: hydro-anthracite +quartz sand with different granulation). Heat exchangers heat the water. Then, the $\mathrm{pH}$ is automatically adjusted, and the water is disinfected with the addition of stabilized sodium hypochlorite. 
Table 1 General technical and computational data for the analyzed swimming pool facility

\begin{tabular}{ll}
\hline Technical data & Value \\
\hline Dimensions of the pool $(\mathrm{m})$ & $12.42 \times 7.22$ \\
The surface of the water surface $\left(\mathrm{m}^{2}\right)$ & 89.67 \\
Pool capacity $\left(\mathrm{m}^{3}\right)$ & 121.06 \\
Personal load on the day of collection (bathers $/ \mathrm{h})$ & 15 \\
Bather dose $\left(\right.$ bathers $\left./ \mathrm{m}^{3} / \mathrm{h}\right)$ & 0.12 \\
Required usable area according to DIN $19643[4]\left(\mathrm{m}^{2} / \mathrm{bather}\right)$ & 4.50 \\
The length of the overflow gutter $(\mathrm{m})$ & 39.28 \\
Circulation performance $\left(\mathrm{m}^{3} / \mathrm{h}\right)$ & 30 \\
Water displaced $\mathrm{V}_{\mathrm{V}}\left(\mathrm{m}^{3}\right)$ & 1.49 \\
Flow by waving $\mathrm{V}_{\mathrm{W}}\left(\mathrm{m}^{3}\right)$ & 3.62 \\
Total water exchange in the basin $($ water recirculation) $(\mathrm{h})$ & 4.00 \\
The capacity of the overflow tank $\left(\mathrm{m}^{3}\right)$ & 12.47 \\
Number of filters & 2 \\
The diameter of the filters $(\mathrm{mm})$ & 1250 \\
Filter surface of a single bed $\left(\mathrm{m}^{2}\right)$ & 1.23 \\
The height of the filter bed $(\mathrm{H}, \mathrm{m})$ & 1.2 \\
The height of the gravel layer with a grain size of 3-5 $\mathrm{mm}(\mathrm{mm})$ & 100 \\
The height of the gravel layer with a granulation of $1-2 \mathrm{~mm}(\mathrm{~mm})$ & 100 \\
The height of the sand layer with a grain size of $0.4-0.8 \mathrm{~mm}(\mathrm{~mm})$ & 400 \\
The height of the anthracite layer with a grain size of $0.8-1.6 \mathrm{~mm}(\mathrm{~mm})$ & 600 \\
Filter cycle time $($ day) & 2 \\
Water for rinsing filters $\mathrm{V}_{\mathrm{R}}\left(\mathrm{m}^{3}\right)$ & 7.36 \\
\hline
\end{tabular}

*They work alternately
Purified water is introduced into the basin through holes located at the bottom of the basin. The personal load on the pool at the moment of water intake was 15 people per hour. Table 1 shows the detailed technical data on the basin and circulation system.

Based on the information obtained from the technical documentation of the facility (Table 1), the total time of water overflows, which is valuable information about the exchange of water in the basin, and thus the time spent in the DBP precursors.

The selected physicochemical parameters of pool water are presented in Table 2. Significant exceedances of standards (according to the Regulation of the Polish Ministry of Health) have been demonstrated in the scope of redox potential (at least $750 \mathrm{mV}$ ), free chlorine (range: 0.3-0.6 $\mathrm{mgCl}_{2} / \mathrm{L}$ ), and bound chlorine ( $\max .0 .3 \mathrm{mgCl}_{2} / \mathrm{L}$ ) [1].

\subsection{The composition of body fluids analog solution}

The mixed composition of a model BFA solution has been prepared based on the literature data [7]. All chemical reagents (BFA components) were purchased as analytical grade (98-99\% purity) and used without additional purification (dissolved in DEMW $(\mathrm{pH}=9.2)$ ). Table 3 presents the concentration of the analyzed compounds in the model solution. The analyzed doses of the model
Table 2 The values of physicochemical parameters of samples taken from the pool intended for swimming

\begin{tabular}{ll}
\hline Parameter & Value \\
\hline $\mathrm{pH}$ & 6.82 \\
Redox potential $(\mathrm{mV})$ & 630 \\
Turbidity (NTU) & 0.43 \\
$\mathrm{UV} 254\left(\mathrm{~m}^{-1}\right)$ & 4.70 \\
Free chlorine $\left(\mathrm{mgCl}_{2} / \mathrm{L}\right)$ & 0.21 \\
Total chlorine $\left(\mathrm{mgCl}_{2} / \mathrm{L}\right)$ & 1.26 \\
Total organic carbon $(\mathrm{mgC} / \mathrm{L})$ & 8.09 \\
Dissolved organic carbon $(\mathrm{mgC} / \mathrm{L})$ & 5.80 \\
Total carbon $(\mathrm{mgC} / \mathrm{L})$ & 12.73 \\
Total nitrogen $(\mathrm{mgN} / \mathrm{L})$ & 2.80 \\
\hline
\end{tabular}

NTU nephelometric turbidity unit

solution were determined based on the German standard DIN 19643 [4] (according to which 1 bather should have an area of $4.5 \mathrm{~m}^{2}$ of water surface at his disposal) and information about the total water exchange in the basin. The time of water recirculation was 1 (theoretical time of the presence of impurities in the basin) and $4 \mathrm{~h}$ (real time for the circulation from which the POOLW came from) (Table 3). 
Table 3 Concentration of body fluid analog (BFA) components in the tested solutions

\begin{tabular}{|c|c|c|c|c|}
\hline \multirow[t]{3}{*}{ Compounds of BFA solution } & \multirow[t]{3}{*}{ CAS number } & \multirow{3}{*}{$\begin{array}{l}\text { Concentration in the stock } \\
\text { solution* }(\mathrm{mg} / \mathrm{L})\end{array}$} & \multicolumn{2}{|c|}{ BFA doses $(\mu \mathrm{L} / \mathrm{L})$} \\
\hline & & & 3.90 & 15.60 \\
\hline & & & \multicolumn{2}{|c|}{$\begin{array}{l}\text { Concentration of } \\
\text { the component } \\
\text { in the BFA solu- } \\
\text { tion }(\mathrm{mg} / \mathrm{L})\end{array}$} \\
\hline Urea & $57-13-6$ & 14,800 & 0.0577 & 0.2309 \\
\hline Ammonium chloride & $12125-02-9$ & 2000 & 0.0078 & 0.0312 \\
\hline Creatinine & $60-27-5$ & 1800 & 0.0070 & 0.0281 \\
\hline Hippuric acid & $495-69-2$ & 1710 & 0.0067 & 0.0267 \\
\hline L-histidine & $71-00-1$ & 1210 & 0.0047 & 0.0189 \\
\hline Sodium phosphate dibasic & $7558-79-4$ & 4300 & 0.0168 & 0.0671 \\
\hline Citric acid & $77-92-9$ & 640 & 0.0025 & 0.0100 \\
\hline Uric acid & $69-93-2$ & 490 & 0.0019 & 0.0076 \\
\hline
\end{tabular}

* $25 \mathrm{~mL}$ of solution corresponds to the volume introduced by a single bather during an hour of physical activity

\begin{tabular}{|c|c|c|c|c|c|c|}
\hline \multirow[t]{2}{*}{ Parameter } & \multicolumn{2}{|c|}{$\begin{array}{l}\text { Matrix: demineral- } \\
\text { ized water (DEMW) }\end{array}$} & \multicolumn{2}{|c|}{$\begin{array}{l}\text { Matrix: tap water } \\
\text { (TAPW) }\end{array}$} & \multicolumn{2}{|c|}{$\begin{array}{l}\text { Matrix: swimming } \\
\text { pool water (POOLW) }\end{array}$} \\
\hline & $3.90 \mu \mathrm{L} / \mathrm{L}$ & $15.60 \mu \mathrm{L} / \mathrm{L}$ & $3.90 \mu \mathrm{L} / \mathrm{L}$ & $15.60 \mu \mathrm{L} / \mathrm{L}$ & $3.90 \mu \mathrm{L} / \mathrm{L}$ & $15.60 \mu \mathrm{L} / \mathrm{L}$ \\
\hline $\mathrm{pH}$ & 7.25 & 6.86 & 7.45 & 7.10 & 6.80 & 6.72 \\
\hline Redox potential $(\mathrm{mV})$ & 480 & 450 & 360 & 320 & 260 & 230 \\
\hline Turbidity (NTU & 0.28 & 0.32 & 0.35 & 0.42 & 0.47 & 0.58 \\
\hline UV254 $\left(\mathrm{m}^{-1}\right)$ & 2.10 & 4.50 & 2.80 & 4.90 & 5.20 & 6.30 \\
\hline Free chlorine $\left(\mathrm{mgCl}_{2} / \mathrm{L}\right)$ & 0.00 & 0.00 & 0.10 & 0.10 & 0.18 & 0.18 \\
\hline Total chlorine $\left(\mathrm{mgCl}_{2} / \mathrm{L}\right)$ & 0.00 & 0.00 & 0.62 & 0.62 & 1.20 & 1.20 \\
\hline Total organic carbon $(\mathrm{mgC} / \mathrm{L})$ & 0.0198 & 0.0842 & 3.26 & 3.32 & 8.29 & 8.62 \\
\hline Dissolved organic carbon (mgC/L) & 0.0174 & 0.0799 & 3.09 & 3.16 & 5.96 & 6.02 \\
\hline Total carbon (mgC/L) & 0.0399 & 0.0944 & 9.64 & 9.70 & 12.86 & 12.92 \\
\hline Total nitrogen (mgN/L) & $>0.20$ & $>0.20$ & $>0.20$ & $>0.20$ & 2.80 & 2.84 \\
\hline
\end{tabular}

NTU, nephelometric turbidity unit
Table 4 Physicochemical parameters of BFA-enriched solutions for the nanofiltration process

\subsection{Characteristics of matrices used for BFA}

In addition to the analysis of POOLW, we analyzed the transport and separation properties of the NF membrane by using DEMW and TAPW, to take into account the importance of the matrices for BFA pollutants. From the prepared BFA stock solution, the designated solutions were withdrawn $(3.90 \mu \mathrm{L} / \mathrm{L}$ and $15.60 \mu \mathrm{L} / \mathrm{L})$ and dosed to the feeds (the reaction time of the matrices with the compounds was $30 \mathrm{~min}$ ). Then, the selected physicochemical parameters were measured. Table 4 summarizes the results of the physicochemical analysis.

\subsection{Methodology of the nanofiltration process}

Asymmetric DowFilmtec ${ }^{\mathrm{TM}}$ flat membranes NF90 (YMNF903001) with the cutoff molar mass distribution of
200-400 Da were used in this study. The NF90 membrane is a full aromatic polyamide-thin film composite membrane with support layers of polysulfone and polyester, with an average pore radius of $0.34 \mathrm{~nm}$, a contact angle of $63.2^{\circ}$, and a root mean square roughness of $142.8 \pm 9.6 \mathrm{~nm}$ [60].

The transmembrane pressure during the filtration was maintained at $0.80 \mathrm{MPa}$. The membranes were placed in a steel filtration cell with a volume of $380 \mathrm{~cm}^{3}$ where the active surface of the membrane was equal to $38.5 \mathrm{~cm}^{2}$. Before starting the process of filtration, the new membranes were conditioned by filtering DEMW to stabilize the permeate flux $\left(J_{0}\right)$. Each cycle was conducted to recover $50 \%$ of the feed. The concentrated retentate was then removed from the cell. After each cycle, the membrane was rinsed with DEMW $\left(J_{R}\right)$ to document the occurrence of fouling and scaling caused by the organic and inorganic 
Table 5 Characteristics of membranes and operating parameters of the filtration process

\begin{tabular}{|c|c|c|c|c|}
\hline Feed & $\begin{array}{l}\text { The flux of demineralized } \\
\text { water } J_{0} 10^{-6}, \mathrm{~m}^{3} / \mathrm{m}^{2} \mathrm{~s}\end{array}$ & $\begin{array}{l}\text { The flux of permeate } \\
J_{v} 10^{-6^{*}}, \mathrm{~m}^{3} / \mathrm{m}^{2} \mathrm{~s}\end{array}$ & $\begin{array}{l}\text { The flux of rinsing water } \\
J_{R} 10^{-6^{* *}}, \mathrm{~m}^{3} / \mathrm{m}^{2} \mathrm{~s}\end{array}$ & $\begin{array}{l}\text { The flux of demineralized water } \\
\text { after cleaning } J_{C} 10^{-6}, \mathrm{~m}^{3} / \mathrm{m}^{2} \mathrm{~s}\end{array}$ \\
\hline DEMW, $3.90 \mu \mathrm{L} / \mathrm{L}$ & 1.32 & 1.27 & 1.32 & 1.36 \\
\hline DEMW, $15.60 \mu \mathrm{L} / \mathrm{L}$ & 1.43 & 1.32 & 1.42 & 1.45 \\
\hline TAPW, $3.90 \mu \mathrm{L} / \mathrm{L}$ & 1.32 & 1.14 & 1.29 & 1.34 \\
\hline TAPW, $15.60 \mu \mathrm{L} / \mathrm{L}$ & 1.32 & 1.05 & 1.31 & 1.34 \\
\hline POOLW, $3.90 \mu \mathrm{L} / \mathrm{L}$ & 1.32 & 1.11 & 1.29 & 1.34 \\
\hline POOLW, $15.60 \mu \mathrm{L} / \mathrm{L}$ & 1.32 & 0.96 & 1.29 & 1.33 \\
\hline
\end{tabular}

*The average value of the nine recorded during the process

**The average value of three rinsing processes

$D E M W$, demineralized water; TAPW, tap water; POOLW, swimming pool water

pollutants. Then the cell was refilled with a new portion of the feed. The treatment process was performed in three consecutive cycles without changing the membrane.

To evaluate the transport properties of the membranes, the volumetric flow rate of DEMW $\left(J_{0}\right)$, permeate $\left(J_{\mathrm{v}}\right)$ (in the course of the proper filtration process), rising water $\left(J_{R}\right)$, carried out each time after the end of the cycle, and DEMW after cleaning $\left(J_{C}\right)$ were determined using the formula: $J_{0}\left(J_{v}, J_{R}, J_{C}\right)=\frac{v}{F \cdot t}\left(\frac{m^{3}}{m^{2} \cdot s}\right)$, where $v$ is the volume of water or permeate $\left(\mathrm{m}^{3}\right), F$ is an active surface area of the membrane $\left(\mathrm{m}^{2}\right)$, and $t$ is the filtration time (s).

The intensity of the reduction of the hydraulic performance of the membrane was determined by determining the value of an intermediate parameter-the relative permeate/DEMW flux (relative permeability) $\alpha=\frac{J_{v}}{J_{0}} \cdot 100(\%)$. It is the quotient of the fluxes determined during the course of filtration of the treated solutions and of DEMW $\left(J_{0}\right)$. This parameter is a simple measure of the disadvantageous phenomena accompanying the process of membrane filtration. Table 5 provides a detailed information on the volume of the demineralized rinsed water flux and after cleaning the membrane with a cellulose sponge. The flux of rinsing water $\left(J_{R}\right)$ and after cleaning $\left(J_{C}\right)$ were determined in an analogous way.

Furthermore, based on the selected parameters, we analyzed the characteristics of pore blockage occurring during the filtration process. There was an irreversible fouling ratio (IFR (\%)), the flux recovery $(F R(\%))$, and the flux recovery after cleaning the membrane $\left(R_{\mathrm{c}}(\%)\right)$ with cellulose materials, which were calculated based on the following formulas: $I R F=\frac{J_{R}-J_{C}}{J_{R}} \cdot 100 ; \quad F R=\frac{J_{C}}{J_{0}} \cdot 100$; $R_{\mathrm{c}}=\frac{J_{\mathrm{C}}}{J_{\mathrm{R}}} \cdot 100$.

To determine the separation properties of the membranes, the percentage of rejection $(R(\%))$ was determined based on the reduction of the values of pollution indicators: $R=\left(1-\frac{c_{\mathrm{p}}}{c_{\mathrm{f}}}\right) \cdot 100$, where $c_{\mathrm{p}}$ and $c_{\mathrm{f}}$ are concentrations (indicator value) of pollutants in the permeate and feed, respectively, (mgC/L or nephelometric turbidity unit (NTU) or $\mathrm{m}^{-1}$ ).

\section{Results and discussion}

Efficient removal of general and DOC from POOLW with pressure membrane processes requires membranes of low threshold limit value. Therefore, it is beneficial to use NF or reverse osmosis to remove precursors and DBPs. In addition, NF has higher values of permeate flux than that of reverse osmosis [61].

NF90 membranes are highly efficient in removing DBPs [62-65]. Moreover, NF membranes have been shown to remove contamination from waters with low concentrations of DOC and specific ultraviolet absorbance (SUVA) was confirmed $[60,62,63]$. In this study, the retention coefficients were found to be diversified - high for haloketone creatinine and low for haloacetic acids and glycine [61, 64, 65]. Moreover, NF90 membrane is classified as hydrophobic, which is good for removing hydrophilic and neutral compounds [64].

Our results show that NF is highly efficient in removing selected pollutants related to human secretions (Fig. 1a-f). The average value of TOC retention ranged from 57.06\% (DEMW, 3.90 $\mu \mathrm{L} / \mathrm{L}$ ) to $87.56 \%$ (DEMW, $15.60 \mu \mathrm{L} / \mathrm{L}$ ). NF showed low efficiency in removing turbidity (Fig. 1a, b). The value of average retention coefficients (turbidity) ranged from $52.58 \%$ (POOLW, $3.90 \mu \mathrm{L} / \mathrm{L}$ ) and $69.54 \%$ (POOLW, $15.60 \mu \mathrm{L} / \mathrm{L}$ ) (Fig. 1e, f). NF showed the highest efficiency based on the values of $U_{254}$, with an average value ranging from $67.72 \%$ (DEMW, $3.90 \mu \mathrm{L} / \mathrm{L}$ ) to $96.65 \%$ (POOLW, $15.60 \mu \mathrm{L} / \mathrm{L}$ ).

Moreover, separating properties were found to be different with regard to the applied doses of BFA. For example, in feeds with DEMW as the matrix, the average value of retention coefficient for organic carbon increased from 
(a)

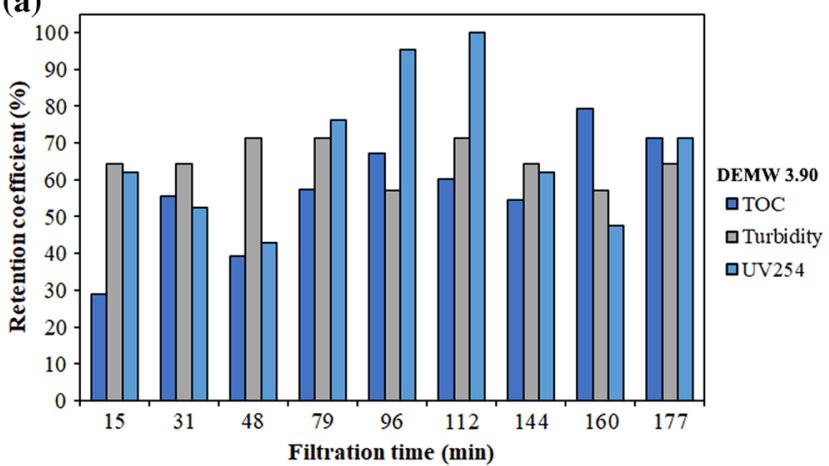

(c)

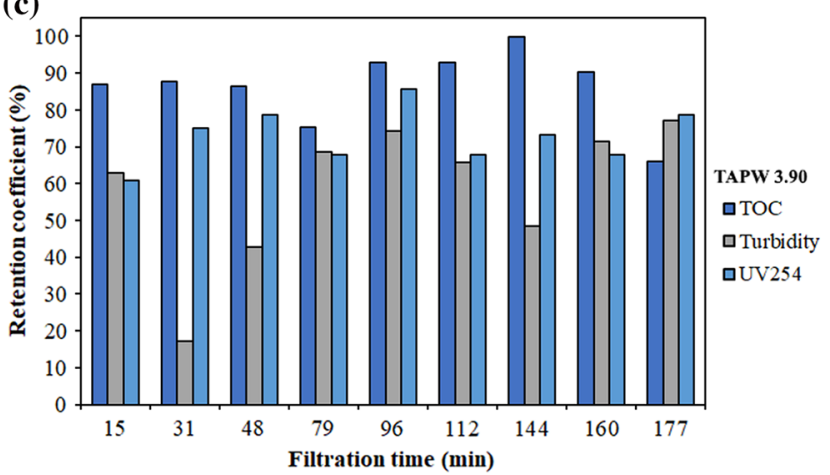

(e)

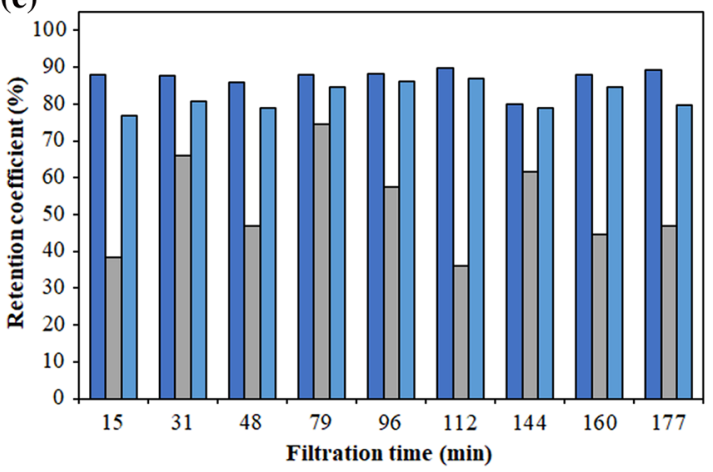

Fig. 1 Separation properties of NF90 membranes during filtration of solutions: a demineralized water with a BFA $(3.90 \mu \mathrm{L} / \mathrm{L})$; b demineralized water with BFA $(15.60 \mu \mathrm{L} / \mathrm{L})$; c tap water with BFA $(3.90 \mu \mathrm{L} / \mathrm{L})$; d tap water with BFA $(15.60 \mu \mathrm{L} / \mathrm{L})$; e swimming

$57.06 \%$ (for $3.90 \mu \mathrm{L} / \mathrm{L}$ ) to $87.56 \%$ (for $15.60 \mu \mathrm{L} / \mathrm{L}$ ) (Fig. 1a, b). Meanwhile, $\mathrm{UV}_{254}$ values increased from $67.72 \%(3.90 \mu \mathrm{L} / \mathrm{L})$ to $80.94 \%(15.60 \mu \mathrm{L} / \mathrm{L})$. There was a significant increase in the values of turbidity and $\mathrm{UV}_{254}$ in addition to BFA after filtration of POOLW (even up to $R=100 \%$ ) (Fig. 1e, f). At the same time, the value of retention coefficients for the total concentration of organic carbon decreased from $87.21 \%$ (for $3.90 \mu \mathrm{L} / \mathrm{L}$ ) to $79.67 \%$ (for $15.60 \mu \mathrm{L} / \mathrm{L}$ ).

The effect of the matrix on the filtration due to the presence of BFA was also significant. There was a difference in the transporting and separating properties of the membranes $[54,55]$. The level of complexity of the (b)

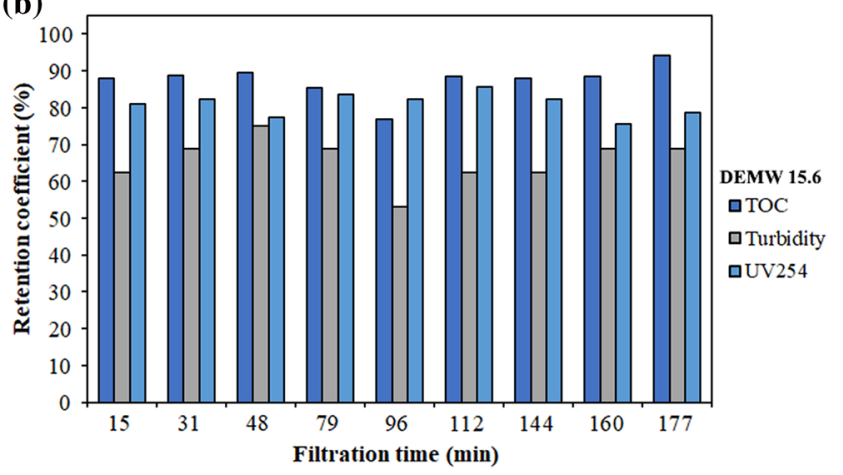

(d)

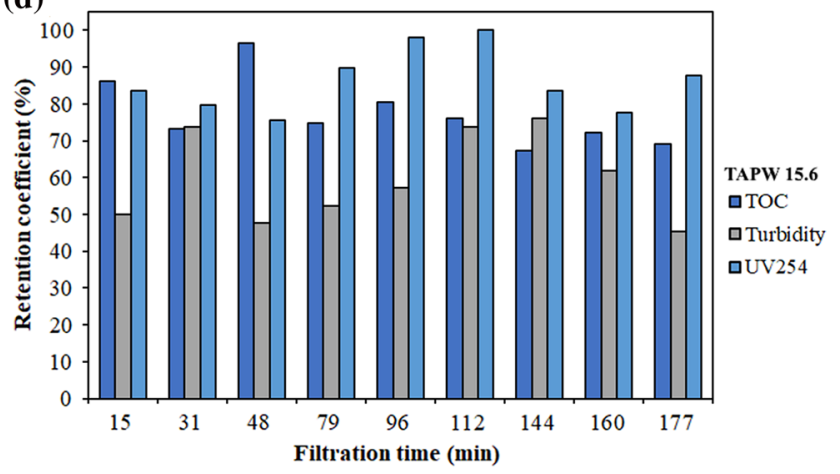

(f)

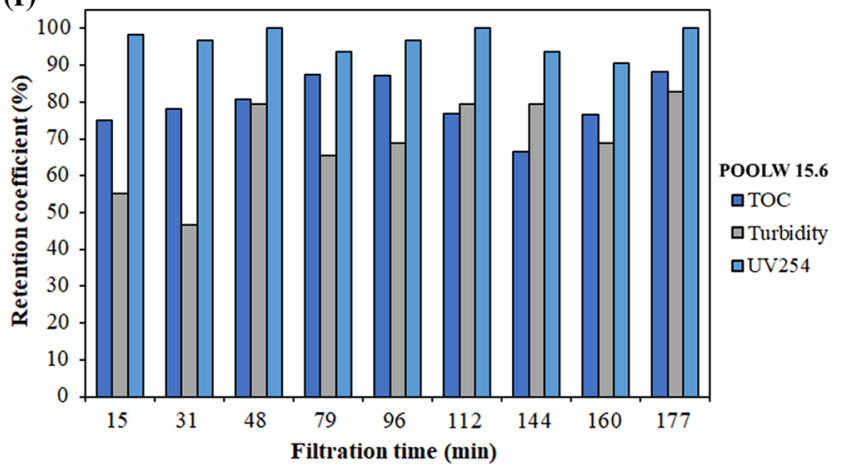

pool water with BFA $(3.90 \mu \mathrm{L} / \mathrm{L})$; f swimming pool water with BFA $(15.60 \mu \mathrm{L} / \mathrm{L}) . B F A$, body fluid analogs; $D E M W$, demineralized water; TAPW, tap water; TOC, total organic carbon; POOLW, pool water

matrix affects the efficiency of NF membranes [62]. In the analyzed processes, the lowest values of contaminants' retention coefficients were obtained for DEMW $(3.90 \mu \mathrm{L} / \mathrm{L})$. This feed showed the lack of foreign compounds from the matrix and low concentration of compounds from the model solution (BFA). BFA (15.60 $\mu \mathrm{L} / \mathrm{L})$ caused an increase in the separation properties of the membrane. This phenomenon was observed for processed with the use of matrices, i.e., TAPW and POOLW, for turbidity retention and $U_{254}$ absorbance coefficients. Meanwhile, separation properties of membranes with respect to reducing the total concentration of organic carbon were not improved. 


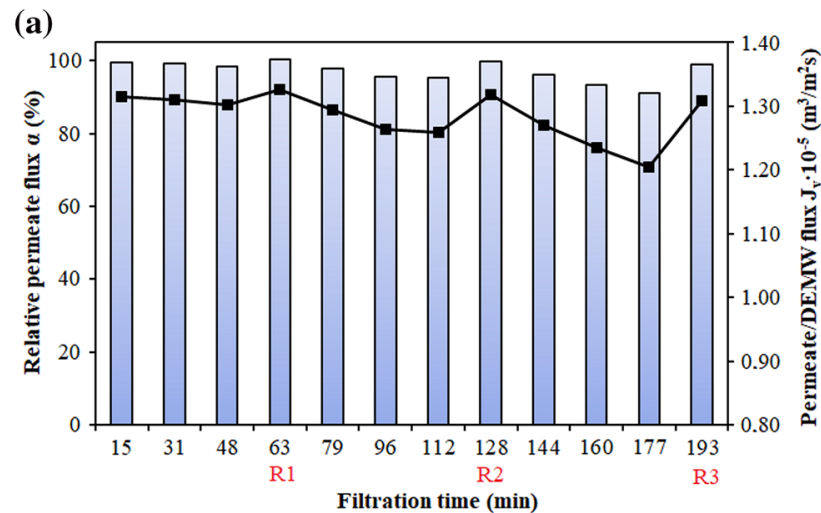

(c)

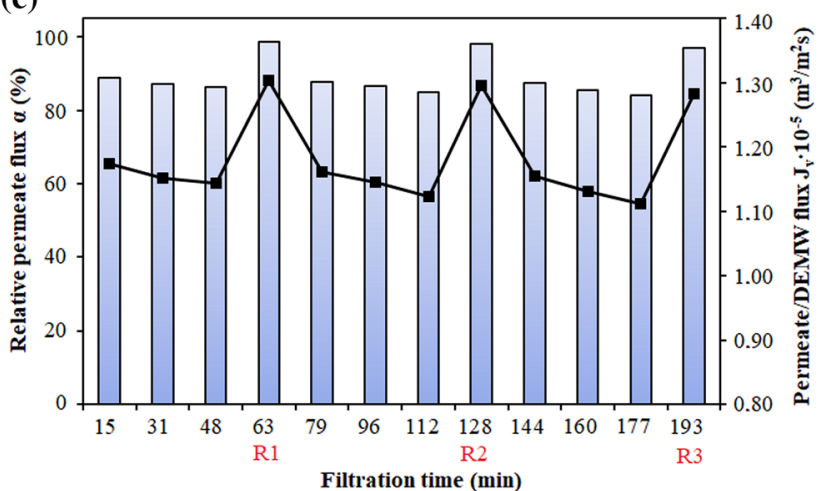

(e)

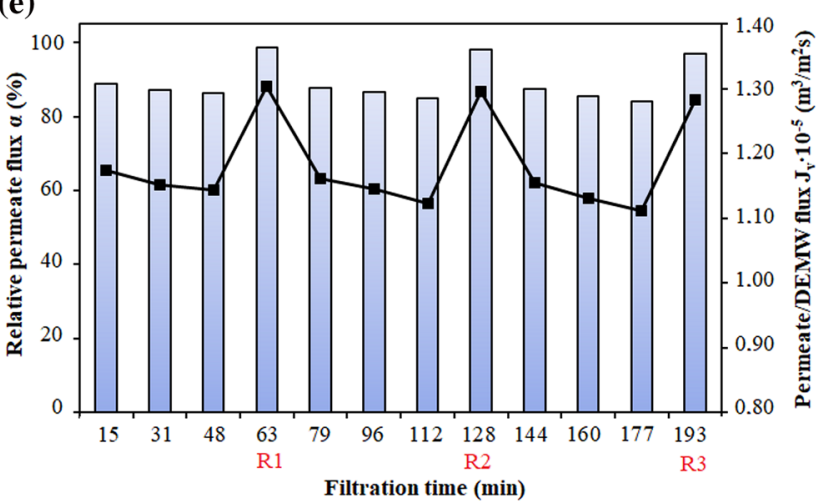

Fig. 2 Transport properties of membranes during nanofiltration processes: a demineralized water with a body fluid analog (BFA) $(3.90 \mu \mathrm{L} / \mathrm{L})$; b demineralized water with BFA $(15.60 \mu \mathrm{L} / \mathrm{L})$; $\mathbf{c}$ tap

The level of complexity of the matrix affects the efficiency of NF membranes [62]. The already-mentioned increase in separation properties is most probably associated with the blockage of pores of the membrane. A significant effect of the matrix on the value of the relative permeability was shown in this study. Furthermore, there was a reduction in the transporting properties of the membrane with an increase in the concentration of BFA (Fig. 2a-f).

The highest value of relative permeability was recorded for NF membranes filtering DEMW $\left(a_{3.90}=99.39 \div 91.01 \%\right.$; $\left.a_{15.60}=98.16 \div 88.84 \%\right)$. The highest intensity of blockage

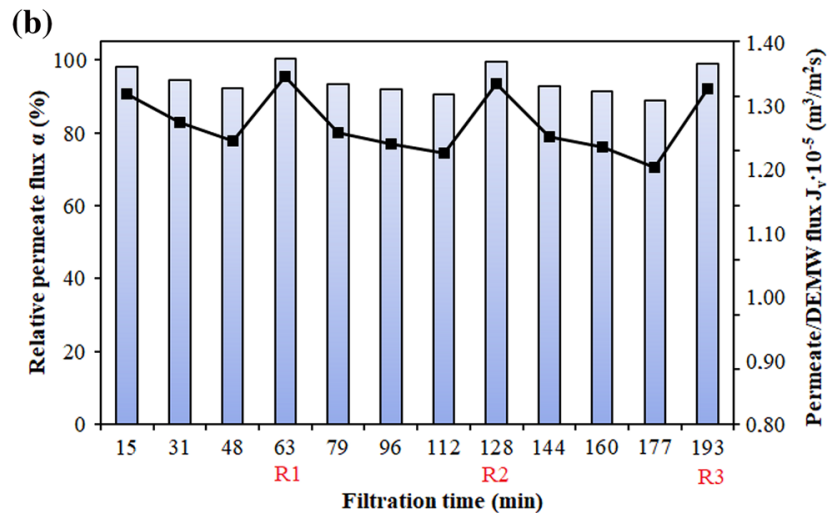

(d)

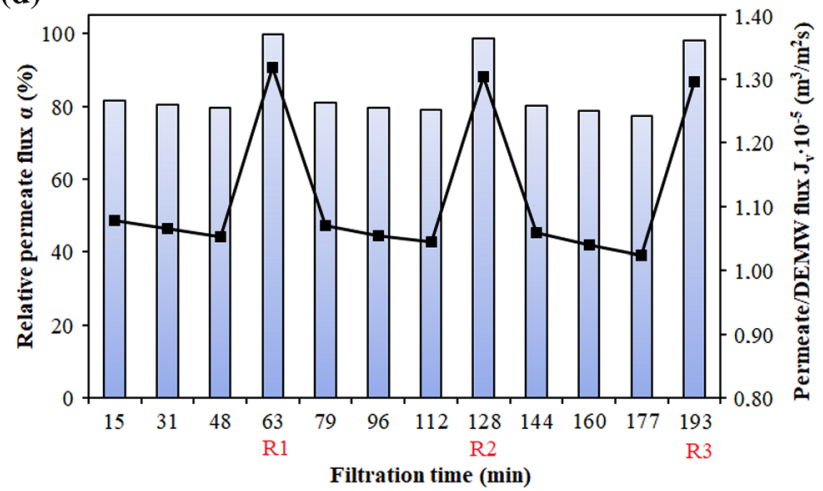

(f)

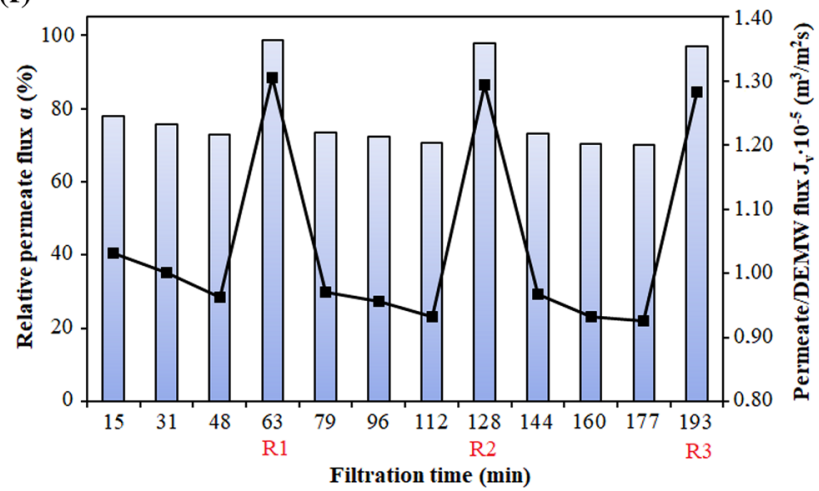

water with BFA $(3.90 \mu \mathrm{L} / \mathrm{L})$; d tap water with BFA $(15.60 \mu \mathrm{L} / \mathrm{L})$; e swimming pool water with BFA $(3.90 \mu \mathrm{L} / \mathrm{L})$; f swimming pool water with BFA $(15.60 \mu \mathrm{L} / \mathrm{L})$

of membrane pores was recorded for feed with POOLW as the matrix $\left(a_{3.90}=88.31 \div 79.32 \% ; a_{15.60}=77.94 \div 70.04 \%\right)$ (Fig. 2e, f). Our preliminary analysis showed that POOLW with BFA as the contaminants showed the highest capacity to block the pores of NF membranes. The turbidity of POOLW was 0.43 NTU, and the concentration of TOC exceeded $8 \mathrm{mgC} / \mathrm{L}$. Addition of BFA model solution contributed to an increase in the pollutants in the feed.

During the course of filtration processes, interim rinsing of the membrane was planned at 63,128 , and $193 \mathrm{~min}$ of the cycle (marked on Fig. 2 under R1, R2, and R3). This allowed us to reset the initial value of relative permeability 
to a large extent. The relative permeability for DEMW with the addition of 3.90 and $15.60 \mu \mathrm{L} / \mathrm{L}$ BFA amounted to $100 \%$ and $99.30 \%$, respectively. The a values for demineralized water matrices after rinsing the membrane was TAPW + BFA and was $97.73 \%$ and $99.24 \%$. In the case of POOLW, the lowest value of a was obtained for both analyzed doses of BFA (97.73\%). However, pore blocking is reversible to a large extent. Mechanical cleaning with the use of cellulose sponge allowed to remove the cake layer formed on the surface of the membrane.

The FR value of DEMW after mechanical cleaning exceeded $100 \%$ in both the analyzed doses of BFA. The designated irreversible fouling coefficients assumed negative values, which confirms that we are dealing with a reversible phenomenon. The filter cake is probably caused by the adhesion of colloidal particles. Moreover, limiting transporting properties of NF membranes by organic compounds is associated with their adsorption on the surface of the membrane [66]. For the purposes of further analyses of the intensity of blocking pores and the level of its reversibility, it is necessary to extend the process in time. Observing phenomena and analysis of recovery of the flux after rinsing will allow to evaluate the necessity of introducing more invasive cleansing methods, including chemical methods.

In the context of POOLW purification, further analysis is necessary to develop a complete procedure for the NF process. Limitation of fouling can be achieved by pretreatment, change in the membrane material (including surface modification), change in operating parameters, and the use of cleaning methods [66].

It should be borne in mind that in actual POOLW purification cycles, the biofouling phenomenon caused by the presence of microorganisms may have a significant role in blocking the pores [66]. Therefore, one of the possibilities to reduce biofouling is to modify the surface of the membrane with graphene, which limits the multiplication of microorganisms [67]. However, it is necessary to ensure the stability of nanoparticles, which will reduce the risk of their penetration into the environment.

Maintaining the transport properties and reducing the effect of biofouling on pressure membranes can also be achieved by using the pre-ozone process $[68,69]$. It has been confirmed that ozone at a concentration of 0.2:0.4 $\mathrm{mgO}_{3} / \mathrm{mgDOC}$ contributes significantly to improve the separation and transport properties of NF membranes [69]. It is necessary to consider the economic costs between the use of pre-ozonation and cleaning with chemicals. It is also necessary to take the factors that damage the structure and decrease the life of NF membranes such as free chlorine, free oxygen, and microorganisms into account while deciding on the method of purification $[70,71]$.
The chemical cleaning methods for NF membranes could include the use of citric acid, hydrochloric acid, or sodium hydroxide, taking into account the diverse nature of the contaminants present in the POOLW [72]. In this study, the effect of only a part of organic compounds present in human body secretions was analyzed. The analysis of the influence of BFA compounds on inorganic compounds, which may contribute to the irreversible blocking of pores, should be extended.

\section{Conclusions}

- NF is a highly efficient process in terms of separation properties of compounds from the BFA solution. Depending on the matrix in which the BFA model solution was dissolved, there was different removal efficiency recorded. Demineralized water matrices with BFA $(3.90 \mu \mathrm{L} / \mathrm{L})$ demonstrated the lowest efficiency in terms of reducing the pollutants. An increase in the separation capacities in the presence of complex matrices is associated with the partial blockage of the pores of the membrane (with NOM and colloidal particles).

- As the number of matrix components increased, the diaphragm transport properties decreased. The highest intensity of membrane pore blockage (by producing a cake layer) was observed for the pool water matrices filtration process with BFA $(15.60 \mu \mathrm{L} / \mathrm{L})$. The process of rinsing the membrane with DEMW, as well as cleaning with a cellulose sponge, allowed for the recovery of the initial flux value.

- Further analyses are necessary to know the individual compounds associated with human body secretions commonly found in pool water matrices. Expanding the observation of phenomena causing the reduction in the life of membrane and elaborating full procedures of NF is highly warranted (pretreatment - treatment-cleaning).

Acknowledgements The authors would like to thank the Polish Ministry of Science and Higher Education for financial support for the work. The work carried out as part of the faculty research grant for young scientists: "An attempt to optimize the process of nanofiltration in the presence of selected anthropogenic pollutants characteristic of swimming pool water." (Grant Number: BKM-508/RIE-4/2018).

\section{Compliance with ethical standard}

Conflict of interest The authors declare that there is no conflict of interest.

Open Access This article is distributed under the terms of the Creative Commons Attribution 4.0 International License (http://creativeco 
mmons.org/licenses/by/4.0/), which permits unrestricted use, distribution, and reproduction in any medium, provided you give appropriate credit to the original author(s) and the source, provide a link to the Creative Commons license, and indicate if changes were made.

\section{References}

1. Regulation of the Minister of Health from November 2015 on the requirements that water in swimming pools should meet (Polish Journal of Laws 2015 item 2016)

2. Chief Sanitary Inspectorate (2014) Wytyczne w sprawie wymagań jakości wody oraz warunków sanitarno-higienicznych na pływalniach [Guidelines on water quality and sanitary conditions at swimming pools]. https://pssegliwice.pis. gov.pl/plikijednostki/wssekatowice/pssegliwice/userfiles/file/ Wytyczne\%20GIS\%20-\%20baseny.pdf. Accessed 5 Dec 2018

3. WHO (2006) Guidelines for safe recreational water environments. Swimming pools and similar environments, vol 2. http:// www.who.int/water_sanitation_health/bathing/srwe2full.pdf. Accessed 5 Dec 2018

4. DIN 19643 (2012) Aufbereitung von Schwimm und Badebeckenwasser [Treatment of swimming pool water]. Berlin, Dusseldorf. https://doi.org/10.31030/1916007

5. Zhang Y, Chu W, Yao D, Yin D (2017) Control of aliphatic halogenated DBP precursors with multiple drinking water treatment processes: formation potential and integrated toxicity. J Environ Sci 58:322-330. https://doi.org/10.1016/j.jes.2017.03.028

6. Li Ch, Wang D, Xu X, Xu M, Wang Z (2017) Spatial variations in the occurrence of potentially genotoxic disinfection by-products in drinking water distribution systems in China. Environ Pollut 31:1463-1468. https://doi.org/10.1016/j.envpol.2017.09.008

7. Carter RAA, Joll CA (2017) Occurrence and formation of disinfection by-products in the swimming pool environment: a critical review. J Environ Sci 58:19-50. https://doi.org/10.1016/j. jes.2017.06.013

8. Yeh RYL, Farre MJ, Stalter D, Tang JYM, Molendijk J, Escher BI (2014) Bioanalytical and chemical evaluation of disinfection byproducts in swimming pool water. Water Res 59:172-184. https ://doi.org/10.1016/j.watres.2014.04.002

9. Farré MJ, Day S, Neale PA, Stalter D, Tang JYM, Escher BI (2013) Bioanalytical and chemical assessment of the disinfection byproduct formation potential: role of organic matter. Water Res 47:5409-5421. https://doi.org/10.1016/j.watres.2013.06.017

10. Glauner T, Waldmann P, Frimmel FH, Zwiener C (2005) Swimming pool water-fractionation and genotoxicological characterization of organic constituents. Water Res 39:4494-4502. https://doi. org/10.1016/j.watres.2005.09.005

11. Nowacka A, Włodarczyk-Makuła M, Macherzyński B (2014) Comparison of effectiveness of coagulation with aluminum sulfate and pre-hydrolyzed aluminium coagulants. Desalin Water Treat 521(19-21):3843-3851. https://doi.org/10.1080/19443 994.2014.888129

12. Acero JL, Benitez FJ, Real FJ, Teva F (2016) Micropollutants removal from retentates generated in ultrafiltration and nanofiltration treatments of municipal secondary effluents by means of coagulation, oxidation, and adsorption processes. Chem Eng J 289:48-58. https://doi.org/10.1016/j.cej.2015.12.082

13. Uhl W, Hartmann C (2005) Disinfection by-products and microbial contamination in the treatment of pool water with granular activated carbon. Water Sci Technol 52(8):71-76. https://doi. org/10.2166/wst.2005.0229
14. Altmann J, Massa L, Sperlich A, Gnirss R, Jekel M (2016) UV254 absorbance as real-time monitoring and control parameter for micropollutant removal in advanced wastewater treatment with powdered activated carbon. Water Res 94:240-245. https://doi. org/10.1016/j.watres.2016.03.001

15. Briancesco R, Meloni P, Semproni M, Bonadonn L (2014) Nontuberculous mycobacteria, amoebae and bacterial indicators in swimming pool and spa. Microchem J 113:48-52. https://doi. org/10.1016/j.microc.2013.11.003

16. Guida M, Gallè F, Mattei ML, Anastasi D, Liguori G (2009) Microbiological quality of the water of recreational and rehabilitation pools: a 2-year survey in Naples, Italy. Public Health 123(6):448451. https://doi.org/10.1016/J.PUHE.2009.03.008

17. Kanan A, Karanfil T (2010) Formation of disinfection by-products in indoor swimming pool water: the contribution from filling water natural organic matter and swimmer body fluids. Water Res 45(12):926-932. https://doi.org/10.1016/j.watre s.2010.09.031

18. Spiliotopoulou A, Hansen KMS, Andersen HR (2015) Secondary formation of disinfection by-products by UV treatment of swimming pool water. Sci Total Environ 520(1):96-105. https://doi. org/10.1016/j.scitotenv.2015.03.044

19. Catto C, Sabrina S, Ginette CT, Manuel R, Robert T (2012) Occurrence and spatial and temporal variations of disinfection byproducts in the water and air of two indoor swimming pools. Int J Environ Res Public Health 9(8):2562-2586. https://doi. org/10.3390/ijerph9082562

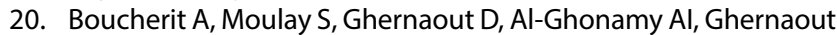
B, Naceur MW, Messaoudene NA, Aichouni M, Mahjoubi AA, Elboughdiri NA (2015) New trends in disinfection by-products formation upon water treatment. J Res Dev Chem 2015:1-27. https://doi.org/10.5171/2015.628833

21. Zwiener C, Richradson SD, De Martin DM, Grumut T, Glauner T, Frimmel FH (2007) Drowning in disinfection byproducts? Assessing swimming pool water. Critical review. Environ Sci Technol 41(2):363-372. https://doi.org/10.1021/es062367v

22. De Laat J, Feng W, Adams Freyfer D, Dossier-Berne F (2011) Concentration levels of urea in swimming pool water and reactivity of chlorine with urea. Water Res 45:1139-1146. https://doi. org/10.1016/j.watres.2010.11.005

23. Chowdhury S, Alhooshani K, Karanfil T (2014) Disinfection byproducts in swimming pool: occurrences, implications and future needs. Water Res 53:68-109. https://doi.org/10.1016/j. watres.2014.01.017

24. Tachikawa M, Aburada T, Tezuka M, Sawamura R (2005) Occurrence and production of chloramines in the chlorination of creatinine in aqueous solution. Water Res 39(2-3):371-379. https ://doi.org/10.1016/j.watres.2004.09.029

25. Teo TLL, Coleman HM, Khan SJ (2015) Chemical contaminants in swimming pools: occurrence, implications and control. Environ Int 76:16-31. https://doi.org/10.1016/j.envint.2014.11.012

26. Panyakapo M, Soontornchai S, Paopuree P (2008) Cancer risk assessment from exposure to trihalomethanes in tap water and swimming pool water. J Envion Sci 20(3):372-378. https://doi. org/10.1016/S1001-0742(08)60058-3

27. Ciorba D, Tataru A, Avram A, Almasi A, Moldovan M (2015) Influence of environmental chloroform concentrations on biophysics skin parameters. Farmacia 63(2):313-317. ISSN: 0014-8237. http://www.revistafarmacia.ro/201502/art-24-Ciorba_313-317. pdf. Accessed 5 Dec 2018

28. Zhanga X, Mineara RA (2006) Formation, adsorption and separation of high molecular weight disinfection by-products resulting from chlorination of aquatic humic substances. Water Res 40:221-230. https://doi.org/10.1016/j.watres.2005.10.024

29. Zhang H, Zhang Y, Shi Q, Ren S, Yu J, Ji F, Luo W, Yang M (2012) Characterization of low molecular weight dissolved natural 
organic matter along the treatment trait of a waterworks using Fourier transform ion cyclotron resonance mass spectrometry. Water Res 46:5197-5204. https://doi.org/10.1016/j.watre s.2012.07.004

30. Bradford WL (2014) What Bathers Put into a Pool: a Critical Review of Body Fluids and a Body Fluid Analog. Int J Aquat Res Educ 8(2):168-181. https://doi.org/10.1123/ijare.2013-0028

31. Łaskawiec E, Madej M, Dudziak M, Wyczarska-Kokot J (2017) The use of membrane techniques in swimming pool water treatment. J Ecol Eng 18(4):130-136. https://doi.org/10.12911/22998 $993 / 74282$

32. Yang L, She Q, Wan MP, Wang R, Chang VWC, Tang ChY (2017) Removal of haloacetic acids from swimming pool water by reverse osmosis and nanofiltration. Water Res 116:116-125. https://doi.org/10.1016/j.watres.2017.03.025

33. Klupfel AM, Glauner T, Zwiener C, Frimmel FH (2011) Nanofiltration for enhanced removal of disinfection by-product (DBP) precursors in swimming pool water-retention and water quality estimation. Water Sci Technol 63(8):1716-1725. https://doi. org/10.2166/wst.2011.213

34. Barbot E, Moulin P (2008) Swimming pool water treatment by ultrafiltration-adsorption process. J Membr Sci 314:50-57. https ://doi.org/10.1016/j.memsci.2008.01.033

35. Reissmann FG, Schulze E, Albrecht V (2005) Application of a combined UF/RO system for the reuse of filter backwash water from treated swimming pool water. Desalination 178:41-49. https://doi.org/10.1016/j.desal.2004.11.027

36. McCormick N, Porter M, Walsh ME (2010) Disinfection byproducts in filter backwash water: implications to water quality in recycle designs. Water Res 44:4581-4589. https://doi. org/10.1016/j.watres.2010.05.042

37. Zhang L, Gu P, Zhong Z, Yang D, He W, Han H (2009) Characterization of organic matter and disinfection by-products in membrane backwash water from drinking water treatment. J Hazard Mater 168:753-759. https://doi.org/10.1007/s1220 9-010-1438-7

38. Zhang LL, Yang D, Zhong ZJ, Gu P (2008) Application of hybrid coagulation-microfiltration process for treatment of membrane backwash water from waterworks. Sep Purif Technol 62:415-422. https://doi.org/10.1016/j.seppur.2008.02.008

39. Al Zahrania S, Mohamad AW (2014) Challenges and trends in membrane technology implementation for produced water treatment: a review. J Water Proc Eng 4:107-133. https://doi. org/10.1016/j.jwpe.2014.09.007

40. Weng SC, Blatchley ER (2011) Disinfection by-product dynamics in a chlorinated, indoor swimming pool under conditions of heavy use: national swimming competition. Water Res 45(16):5241-5248. https://doi.org/10.1016/j.watres.2011.07.027

41. Keuten MGA, Peters MCFM, Daanen HAM, de Kreuk MK, Rietveld LC, van Dijk JC (2014) Quantification of continual anthropogenic pollutants released in swimming pools. Water Res 53:259-270. https://doi.org/10.1016/j.watres.2014.01.027

42. Wang YN, Tang ChY (2011) Fouling of nanofiltration, reverse osmosis, and ultrafiltration membranes by protein mixtures: the role of inter-foulant-species interaction. Environ Sci Technol 45(15):6373-6379. https://doi.org/10.1021/es2013177

43. Filloux E, Gallard H, Croue JP (2012) Identification of effluent organic matter fractions responsible for low-pressure membrane fouling. Water Res 46:5531-5540. https://doi. org/10.1016/j.watres.2012.07.034

44. Hera N, Amy G, Plottu-Pecheux A, Yoon Y (2007) Identification of nanofiltration membrane foulants. Water Res 41:3936-3947. https://doi.org/10.1016/j.watres.2007.05.015

45. Yu W, Liu T, Crawshaw J, Liu T, Graham N (2018) Ultrafiltration and nanofiltration membrane fouling by natural organic matter: mechanisms and mitigation by pre-ozonation and $\mathrm{pH}$. Water Res 139:353-362. https://doi.org/10.1016/j.watres.2018.04.025

46. Baker RW (2012) Membrane technology and applications. Wiley, Hoboken. https://doi.org/10.1002/9781118359686

47. Bodzek M, Konieczny K (2005) Wykorzystanie procesów membranowych w uzdatnianiu wody [The use of membrane processes in water treatment]. Projprzem-EKO. ISBN: 8392219406

48. Zhang R, Shi W, Yu Sh, Wang W, Zhang Z, Zhang B, Li L, Bao X (2015) Influence of salts, anion polyacrylamide and crude oil on nanofiltration membrane fouling during desalination process of polymer flooding produced water. Desalination 373:27-37. https://doi.org/10.1016/j.desal.2015.07.006

49. Zhang X, Guo Z, Zhang C, Luan J (2016) Exploration and optimization of two-stage vacuum membrane distillation process for the treatment of saline wastewater produced by natural gas exploitation. Desalination 385:117-125. https://doi. org/10.1016/j.desal.2016.01.021

50. Han G, de Wit JS, Chung TSh (2015) Water reclamation from emulsified oily wastewater via effective forward osmosis hollow fiber membranes under the PRO mode. Water Res 81:54-63. https://doi.org/10.1016/j.watres.2015.05.048

51. Li Ch, Song Ch, Tao P, Sun M, Pan Z, Wang T, Shao M (2016) Enhanced separation performance of coal-based carbon membranes coupled with an electric field for oily wastewater treatment. Sep Purif Technol 168:47-56. https://doi.org/10.1016/j. seppur.2016.05.020

52. Zirehpoura A, Rahimpoura A, Ulbricht M (2017) Nano-sized metal organic framework to improve the structural properties and desalination performance of thin film composite forward osmosis membrane. J Membr Sci 531:59-67. https://doi. org/10.1016/j.memsci.2017.02.049

53. Zhang Y, Van der Bruggen B, Chen GX, Braeken L, Vandecasteele C (2004) Removal of pesticides by nanofiltration: effect of the water matrix. Sep Purif Technol 38:163-172. https://doi. org/10.1016/j.seppur.2003.11.003

54. Kudlek E, Dudziak M, Bohdziewicz J (2016) Influence of inorganic ions and organic substances on the degradation of pharmaceutical compound in water matrix. Water 8(11):1-18. https://doi. org/10.3390/w8110532

55. Burdzik-Niemiec E, Dudziak M (2017) The influence of water matrix on the separation of selected estrogens and xenoestrogens by nanofiltration. Inż Ekol 18(1):33-41. https://doi. org/10.12912/23920629/65858

56. Acero JL, Benítez FJ, Real FJ, Rodriguez E (2016) Influence of membrane, $\mathrm{pH}$ and water matrix properties on the retention of emerging contaminants by ultrafiltration and nanofiltration. Desalin Water Treat 57(25):11685-11698. https://doi. org/10.1080/19443994.2015.1044919

57. Hilal N, Al-Zoubi H, Darwish NA, Mohammad AW, Abu Arabi M (2004) A comprehensive review of nanofiltration membranes: treatment, pre-treatment, modelling and atomic force microscopy. Desalination 170:281-308. https://doi.org/10.1016/j.desal .2004.01.007

58. Košutić K, Dolar D, Kunst B (2006) On experimental parameters characterizing the reverse osmosis and nanofiltration membrane active layer. J Membr Sci 282:109-114. https://doi. org/10.1016/j.memsci.2006.05.010

59. Potter BB, Wimsatt J (2009) Method 415.3, Rev. 1.2: determination of total organic carbon and specific UV absorbance at $254 \mathrm{~nm}$ in source water and drinking water. U.S. Environmental Protection Agency, Washington. https://cfpub.epa.gov/si/ si_public_record_report.cfm?Lab=NERL\&dirEntryld=214406. Accessed 5 Dec 2018

60. Lin YL, Tsai JZ, Hung CH (2018) Using in situ modification to enhance organic fouling resistance and rejection of pharmaceutical and personal care products in a thin-film composite 
nanofiltration membrane. Environ Sci Pollut Res Int 2018:1-12. https://doi.org/10.1007/s11356-018-3234-1

61. Yoou Y, Leuptow RM (2005) Removal of organic contaminants by RO and NF membranes. J Membr Sci 261:76-86. https://doi. org/10.1016/j.memsci.2005.03.038

62. Sentana I, Rodriguez M, Sentana E, M'Birek C, Prats D (2010) Reduction of disinfection by-products in natural waters using nanofiltration membranes. Desalination 250:702-706. https:// doi.org/10.1016/j.desal.2009.05.024

63. Dubowski Y, Greenberg-Eitan R, Rebhun M (2018) Removal of trihalomethane precursors by nanofiltration in low-SUVA drinking water. Water 10(1370):1-11. https://doi.org/10.3390/w1010 1370

64. Bond T, Golsan EH, Parsons SA, Jefferson B (2010) Disinfection by-product formation of natural organic matter surrogates and treatment by coagulation, MIEX ${ }^{\circ}$ and nanofiltration. Water Res 44:1645-1653. https://doi.org/10.1016/j.watres.2009.11.018

65. Al Zazouli M, Kalankesh LR (2017) Removal of precursors and disinfection byproducts (DBPs) by membrane filtration from water; a review. J Environ Health Sci Eng 15(25):1-11. https:// doi.org/10.1186/s40201-017-0285-z

66. Rezakazemi M, Dashti A, Harami HR, Hajilari N, Inamuddin (2018) Fouling resistant membranes for water reuse. Environ Chem Lett 16:715-763. https://doi.org/10.1007/s10311-018-0717-8

67. Anand A, Unnikrishnanet B, Mao JY, Lin HJ, Huang CC (2018) Graphene-based nanofiltration membranes for improving salt rejection, water flux and antifouling-A review. Desalination 429:119-133. https://doi.org/10.1016/j.desal.2017.12.012
68. Vatankhah H, Murray CC, Brannum JW, Vanneste J, Bellona Ch (2018) Effect of pre-ozonation on nanofiltration membrane fouling during water reuse applications. Sep Purif Technol 205:203211. https://doi.org/10.1016/j.seppur.2018.03.052

69. Byun S, Taurozzi JS, Tarabara VV (2015) Ozonation as a pretreatment for nanofiltration: effect of oxidation pathway on the permeate flux. Sep Purif Technol 149:174-182. https://doi. org/10.1016/j.seppur.2015.05.035

70. Abdel-Fatah MA (2018) Nanofiltration systems and applications in wastewater treatment: review article. Ain Shams Eng J 9:3077-3092. https://doi.org/10.1016/j.asej.2018.08.001

71. Dolar D, Vuković A, Ašperger D, Košutić K (2011) Effect of water matrices on removal of veterinary pharmaceuticals by nanofiltration and reverse osmosis membranes. J Environ Sci 23(8):1299-1307. https://doi.org/10.1016/S1001-0742(10)60545 $-1$

72. Aguiar A, Andrade L, Grossi L, Pires W, Amaral M (2018) Acid mine drainage treatment by nanofiltration: a study of membrane fouling, chemical cleaning, and membrane ageing. Sep Purif Technol 192:185-195. https://doi.org/10.1016/j.seppu r.2017.09.043

Publisher's Note Springer Nature remains neutral with regard to jurisdictional claims in published maps and institutional affiliations. 